\title{
LGTN Gene
}

National Cancer Institute

\section{Source}

National Cancer Institute. LGTN Gene. NCI Thesaurus. Code C92527.

This gene plays a role in intracellular transport and may be involved in translational regulation. 